\title{
A Comparative study of Marital Adjustment among Employed and Unemployed Married Women of Urban and Rural Area
}

\author{
Dr. Krishna J. Vaghela*
}

\section{ABSTRACT:}

The aim of the present investigation is to study marital adjustment between employed and unemployed married women of urban and rural area. The sample of the present study consisted of 120 married women and their range between 23 - 38 years. [30 employed and 30 unemployed women from urban area and 30 employed and 30 unemployed women from rural area.] The marital adjustment inventory was administered to all participants. The data was analyzed using means, SD and $\mathrm{t}$ - value. The results are discussed and conclusion is down. The main findings showed that there was a significant difference between employed and unemployed married women of urban area in respect to their marital adjustment scores. As regarding to rural area significant difference were also found between employed and unemployed married women on their marital adjustment.

Keywords: Marital adjustment, Employed, Unemployed, Married women.

\section{INTRODUCTION}

Status of women in the society has been changing fast due to multiple factors such as, increased level of education, urbanization, awareness of right, industrialization, etc. Social changes have also improved the status of women. Education has brought revolutionary changes among women. More and more women prefer to be engaged in some kind of employment, so that they can contribute financially to their family. But attitude towards women especially married women and their role in family has remained the same, as even today taking care of the family and children is considered as their primary responsibility. Most of the non working women are full time housewives who spend most of their time at home attending to their children, husband and domestic chores. They have freedom to go about their day at will and can come home whenever they like to attend to their home. This is where they differ from working married women. The working married women have the double burden of housework and a job outside the home, they have work in two environments, one is the office environment and the other is home environment and both are vastly different from one to another. It is an accepted fact that working married women have greatly changed their family lives. Her employment not only affects her personality but also her family relationship and is also liable to face crisis of adjustment.

*Assoc. Prof. \& Head, Dept. of Psychology, Yogiji Maharaj Mahavidyalaya, Dhari (Guj) 


\section{A Comparative study of Marital Adjustment among Employed and Unemployed Married Women of Urban and Rural Area}

Adjustment:- The ability of humans to survive in stressful environment by monogenetic means. Originally adjustment was rewarded as little more than the avoidance of male adjustment but then became a goal for therapy with the emergence of the humanistic approaches to psychotherapy.

Marital adjustment:- "The state in which there is an overall feeling in husband and wife of happiness and satisfaction with their marriage and with each other". Marital adjustment is a lifelong process, although in the early days of marriage one has to give serious consideration. In marriage two persons adjust to each other. Marital adjustment is a social phenomenon.

Many of attempts have been made to access the quality of marital relationship using such concepts of 'marital adjustment', success stability, satisfaction, consensus, adoption, cohesion, integration, etc. The marital adjustment is varied of concept. The success marital life much depends upon the succession marital adjustment by the husband and wife. Some of the relevant studies done on working and non working married women in relation to their marital adjustment are mentioned here, Mathur Nathawet (1990) investigated that in respect to marital adjustment working women reported significantly better marital adjustment. Adegoke (1987), Iloyd (1980), Rogers (2003) reported that working class women are generally more satisfied with their lives than non working women. Chaudhari \& Patel (2009) found no significant relationship between marital adjustment and place of urban and rural area of married female respondent. Kazmil, et. al. (2010) found that economic resources play a important role in marital adjustment. Kausar (2003) found no significant difference between marital adjustment of working women. Jamabr \& Orche (2012) also found no significant marital difference in working and non working women.

Rani (2013) found that non working wives face more marital adjustment problems. Bhardwaj (2007), Joshi (2007), Patoliya (2009) also reported that working women have better adjustment. Joshi (2011) observed social relations responsibility had significant impact on quality of life of married women. Gupta \& Nafis (2014) found that non working female scored higher on marital adjustment than working females. Hashani, Khurshid, Hassan (2007) found working married women have to face more problems in their married life as compare to non working married women. Tiwari \& Bisht (2012) investigated marital adjustment of working and non working women, results indicated that non working women were better at marital adjustment. About discussion about married working women's adjustment life it is need of time to undertake studies. Today most of married women are employed. They are expanding their lives to include a career, they must also maintain their traditional role as a wife, mother at home. The adjustment and marital relationship are major challenges in most of the families of urban and rural area. Therefore the present study aims to study of marital adjustment among employed and unemployed married women of urban and rural area. 


\section{A Comparative study of Marital Adjustment among Employed and Unemployed Married Women of Urban and Rural Area}

\section{OBJECTIVES}

Some special objectives are needed to frame to study the problem. The main objectives are furnished as under:-

a. To study and compare the difference in marital adjustment between employed and unemployed married women of urban area.

b. To study and compare the difference in marital adjustment between employed and unemployed married women of rural area.

\section{HYPOTHESIS}

1. There are significant differences between employed and unemployed married women of urban area in relation to marital adjustment.

2. There are significant differences between employed and unemployed married women of rural area in relation to marital adjustment.

\section{METHODOLOGY}

\section{Sample:}

Representative sample of 120 married women [employed and unemployed women both - age range 23-38] selected from various rural area and urban area of Junagadh district were taken for the present study. A total 120 married women of which 60 were employed and 60 were unemployed. (30 employed and 30 unemployed women from urban area as well as 30 employed and 30 unemployed women from rural areas.) The sample was consists of only married women. All participants were matched on the variables of age, gender, marital status, etc. Random sampling technique was used to selection the participants

\section{Tools:}

Personal data sheet developed by investigator was used to collected some necessary information. The marital adjustment inventory developed by P. kumar and rohtagi was used to measure marital adjustment of employed and unemployed married women. The reliability of the test is 0.84 and validity is 0.71 .

\section{Procedure:}

The present study conduct on 120 employed and unemployed married women of urban and rural area. After establishing report with the participants the questionnaire were administrated with the necessary instructions and the data was collected. All the participants were assured that their responses would be kept confidential. Finally obtained result were statistically analyzed and discussed accordingly. 


\section{Statistical Treatment:}

The investigator put the data edited and coded together in a carefully designed table for the statistical analysis mean; SD and t-test were used to analysis the data. The results of analyses presented in the table one and two.

\section{RESULTS \& DISCUSSION}

The purpose of the present research was to study of marital adjustment among employed and unemployed married women of urban and rural area. Table-1 showing and analysis of hypothesis that, "there are significant difference in marital adjustment between employed and unemployed married women of urban area. Table-1 reveals there is significant difference between two comparative groups in respect to their score of marital adjustment. Thus, the t-test revealed statistically significant difference between the mean number of employed and unemployed married women and t-value is 3.82. Thus, the hypothesis is accepted and it is concluded that employed women of urban area are better in their marital adjustment than unemployed women of urban area. Hypothesis-2 "There is significant difference in marital adjustment between employed and unemployed married women of rural area. To assess this hypothesis t-test was used, results suggested that the score on marital adjustment of employed and unemployed married women of rural area are significantly differ. Therefore hypothesis- 2 also accepted and it is concluded that employed married women of rural area are better in their marital adjustment than unemployed married women of rural area.

Table-1: Difference between employed and unemployed married woman of urban area regarding to their marital adjustment.

\begin{tabular}{|c|c|c|c|c|c|}
\hline Married women & No. & Mean & S.D. & t-ratio & Sig. \\
\hline Employed & 30 & 21.40 & 2.07 & 3.82 & 0.01 \\
\hline Unemployed & 30 & 18.70 & 3.27 & & \\
\hline
\end{tabular}


Table-2 : Difference between employed and unemployed married women at rural area regarding to their marital adjustment

\begin{tabular}{|c|c|c|c|c|c|}
\hline Married women & No. & Mean & S.D. & t-ratio & Sig. \\
\hline Employed & 30 & 20.09 & 2.09 & 3.4 & 0.01 \\
\cline { 1 - 4 } Unemployed & 30 & 17.80 & 2.98 & & \\
\hline
\end{tabular}

The present study concluded that employed married women have better marital adjustment than unemployed married women. Several researches are also in line with the present findings. [Mathur \& Nathawat (1990), Adegoke (1987), Rogers (2003), Joshi (2007), Patoliya (2009), Rani (2013)] As employed married women have better positive relation with others and personal growth as well as employed married women can always create a healthy atmosphere for their marital adjustment. Because the employed women highly educated. She can well judge her household problems and solve than with easy. On other side unemployed married women cannot solve their problems. Because of less information about that problematic issue. So that this effects her marital life also and this cause marital maladjustment.

\section{CONCLUSION:}

The result of the present study confirm significant difference between employed and unemployed married women of urban area in relation to their marital adjustment score. As regarding to rural area's there are also found significant differences between employed and unemployed married women on their marital adjustment scores. The employed married women are better in their marital adjustment than unemployed married women of urban as well as rural area.

\section{ACKNOWLEDGEMENT}

The of the present study sincerely acknowledgement all occupational centers and the under thank all the participants for their time and kind cooperation, as well as responsible entities which kindly helped in the study.

\section{REFERENCES}

1. Aggarwal, J. (1998) Status of Women, Well Publishers, Jaipur.

2. Baniasadi, (2002) The Study of Some Social and Factors on Marital Adjustment, Human Science Manazine, Special Edition for Psychology. 
3. Carret, H. E. (1996) Statistics in Education and Psychology, Deep \&Deep Publications, Pvt. Ltd. Mumbai.

4. Gupta \& Nafic (2014) Dose Marital Adjustment and Psychological well being differ in working and non working female, International Journal of Research Engineering \& Social Science, Vol. -4, Issue -3, March 2014.

5. Hashami, Khurshid, Hassan (2007) Marital Adjustment, Stress and Depression among Working and non working Married Women, Journal of Medical Science, Vol.2, No. 1.

6. Hussani, Sharma (1994) Marital Adjustment its correlation among Working and non working Women, Journal of Personality and Clinical Studies, 1 (2).

7. Mangal, S. K. (1992) Statistics in Psychology and Education, Tata McGraw Hill Pub. Company Ltd. New Delhi.

8. Mckiney, (1949) Psychology of Personal Adjustment, ( $2^{\text {nd }}$ ed.) New York.

9. Rout, Cooper, Kerslake (1985) "Working and non-working mother". A comparative study, women in management review vol.12.

10. Shukla, K. C. ( 2005 ) Encyclopaedic dictionary of psychology, Commonwealth Publishers, Ansari road, Darya Gang, New Delhi. 